\title{
ПРОСКТНИЙ ПІДХІД У СФЕРІ ПЛАНУВАННЯ ІНТЕГРОВАНОГО РОЗВИТКУ ТЕРИТОРІАЛЬНИХ ГРОМАД
}

\author{
Вяхірєв М. О.
}

\section{ВСТУП}

На сучасному етапі державотворення демократизація публічного управління та адміністрування, передача органам місцевого самоврядування значних повноважень для вирішення питань суспільного розвитку громад ставить перед органами управління складні і неординарні завдання. В умовах об'єднання територіальних громад ці питання набувають значної актуальності. При вдосконаленні процесів реформування української економіки i розвитку ринку місцевих послуг сфера управління в межах територіальної громади стає сферою особливих відносин економіки і влади, i тут мають діяти особливі механізми узгодження соціальних, економічних і політичних інтересів влади, бізнесу та населення. Із метою досконалої розробки, прийняття i реалізації ефективних рішень суспільні відносини територіальної громади повинні розумітися як єдине ціле, у взаємозв'язку і взаємодії іiі основних елементів. Сьогодні, коли органи місцевого самоврядування наділені значними повноваженнями і можливостями визначати напрямки ефективного соціальноекономічного розвитку своїх громад, виникає надзвичайно велика потреба у запровадженні адекватних управлінських інструментів у практику діяльності місцевої влади. До таких інструментів, безумовно, відноситься планування інтегрованого розвитку територіальної громади, ефективність застосування якого визнана міжнародною спільнотою.

Актуальність визначених сучасних напрямів планування інтегрованого розвитку громад полягає в підвищенні важелів багатофункціонального розвитку в економічному зростанні як держави, так і їі окремих частин, децентралізації влади та передачі значних повноважень на місцевий рівень. Потреба в запровадженні сучасних управлінських практик знає більш вагомою в сучасних реаліях сьогодення.

Сучасний розвиток проєктних підходів у сфері інтегрованого планування територіальної громади як складової частини публічного управління та адміністрування недостатньо досліджений, але у цьому науковому напрямі $\epsilon$ певні наробки. Окремі роботи стосуються 
європейської інтеграційних процесів, також розглядається інтегрований розвиток міст. Міжнародний досвід інтегрованого розвитку міст достатньо представлений у науковій літературі, але цей досвід потребує вітчизняної адаптації. Сьогодення потребує грунтовного вивчення питань ефективного вирішення проблем інтегрованого розвитку територіальних громад.

\section{1. Планування інтегрованого розвитку територіальних громад в умовах трансформації суспільних відносин}

У сучасних умовах становлення громадянського суспільства у країні особливий наголос робиться на визначення питань сталого розвитку громад та забезпечення його довготривалості. Сучасним інструментом впровадження принципів сталого розвитку, що спрямовує досягнення та реалізацію домовленостей між громадою, владою, бізнесом стосовно довгострокових пріоритетів розвитку територіальної громади, $\epsilon$ інтегрований розвиток. Визначення планування інтегрованого розвитку громад передбачається через стимулювання розроблення із залученням громадськості та зацікавлених сторін та затвердження органами місцевого самоврядування концепцій інтегрованого розвитку громад та планів дій із реалізації їхніх положень. Політика у сфері розвитку громад та територій щодо інтегрованого розвитку об'єднаних територіальних громад грунтується на положеннях міжнародного рівня та спрямована на реалізацію Цілі № 11 «Сталий розвиток міст та громад. Забезпечення відкритості, безпеки, життєстійкості й екологічної стійкості міст і населених пунктів» Цілей Сталого Розвитку ООН, затверджених 25 вересня 2015 року Резолюцією Генеральної Асамблеї ООН «Перетворення нашого світу: Порядок денний в області сталого розвитку на період до 2030 року» ${ }^{1}$, пункту 11 статті 1 Указу Президента України від 30.09.2019 № 722/2019 «Про Цілі сталого розвитку України на період до 2030 року» ${ }^{2}$ та основних положень Лейпцизької хартії «Міста Свропи на шляху сталого розвитку» ${ }^{3}$. Основні стратегічні цілі інтегрованого розвитку європейських країн, визначені Лейпцизькою хартією «Міста Європи на шляху до сталого розвитку», беззаперечно, створюють підвалини для

\footnotetext{
1 «Перетворення нашого світу: Порядок денний в області сталого розвитку на період до 2030 року» Резолюція Генеральної Асамблеї OOH. URL : http://sdg.org.ua/ua/resources-2/344-2030-2015 (дата звернення: 19.11.2020).

2 «Про Цілі сталого розвитку України на період до 2030 року» Указ Президента України від 30.09.2019 № 722/2019. URL : https://www.president.gov.ua/documents/ 7222019-29825 (дата звернення: 01.12.2020).

3 Лейпцизька Хартія «Міста Європи на шляху сталого розвитку». URL : http:/ /2.auc.org.ua/sites/default/files/leypcizka_hartiya.pdf (дата звернення: 10.11.2020).
} 
напрацювання концепцій інтегрованого розвитку міст не лише у країнах Європи, а й у тих країнах, що обрали для себе європейський вектор розвитку й продовжують рухатися цим шляхом. Лейпцизька хартія стійких європейських міст грунтується на тому, що інтегрований підхід до міського планування - це необхідна передумова для довгострокового розвитку європейських міст. Згідно із цим документом, політика інтегрованого розвитку міських територій $\epsilon$ процесом, у якому координуються просторові і тимчасові аспекти основних напрямів міського розвитку. Політика інтегрованого розвитку населених пунктів реалізується через так звані інтегровані плани місцевого планування та розвитку. Вони забезпечують просторову, тимчасову і фактичну координацію та інтеграцію різних політик, планові ресурси для досягнення поставлених цілей із використанням специфічних інструментів. Проте європейські аналітики чітко розуміють, що варто підтримувати та впроваджувати інтегрований розвиток і для решти самоврядних територій. В умовах об'єднання територіальних громад та подальшого їх розвитку питання синергетичного ефекту поєднання просторового розвитку та пріритетних завдань місцевого спрямування є вельми актуальним та визначальним для вдосконалення трансформаційних процесів децентралізації повноважень.

Напрями запровадження інтегрованого розвитку територіальних громад стають більш ефективними через розроблення із залученням громадськості, учасників та зацікавлених сторін та затвердження органами місцевого самоврядування концепцій інтегрованого розвитку громад та планів дій з реалізації їх положень. Концепція інтегрованого розвитку громади - це документ стратегічного планування, що визначає довгострокові, міждисциплінарні, просторові та соціальноекономічні пріоритети розвитку громади, розробляється із залученням місцевих мешканців та інших заінтересованих сторін, $\epsilon$ передумовою розроблення містобудівної документації на місцевому рівні на принципах сталого розвитку 3 метою підвищення якості життя, доступності та рівності можливостей, сприяння розвитку соціальних відносин громадян та ділової активності, оптимізації адміністративної діяльності, координується з державними і регіональними програмами розвитку. Плани дій із реалізації положень концепцій інтегрованого розвитку громад розробляються на основі кращих практик інтегрованого розвитку громад та забезпечують узгодження містобудівної документації, програм соціально-економічного розвитку відповідних адміністративно-територіальних одиниць, цільових програм з інших питань місцевого самоврядування, місцевих бюджетів із положеннями концепцій. При цьому потребує подальшої розробки та 
вдосконалення механізми планування інтегрованого розвитку громад в умовах децентралізації.

За підтримки Програми «U-LEAD з Свропою» представники органів місцевого самоврядування брали участь у програмі «Інтегроване просторове планування для об'єднаних територіальних громад». Програма була спрямована на підвищення компетенцій представників громад у питаннях стратегічного просторового розвитку та сталого землекористування. Участь у програмі визначала розробку учасниками концепції стратегічного просторового розвитку під керівництвом міжнародної команди експертів. Цей документ дозволяє запланувати довгостроковий інтегрований розвиток всієї території громад, 3 урахуванням національного та регіонального контекстів, з акцентом на стале використання природніх ресурсів та земель. Відповідаючи на просторові, економічні, екологічні та соціальні виклики, що стоять зараз перед об'єднаною громадою, концепція просторового розвитку передбачає також створення концепцій розвитку соціальної та транспортної інфраструктури, екологічного аудиту та ландшафтного плану території громад, а також розробку пілотних проєктів залучення інвестицій ${ }^{4}$.

Напрями роботи програми визначали розробку концепції сталого розвитку громади в контексті регіону та всієї країни, підвищення компетенцій співробітників громад у питаннях просторового розвитку, планування стратегічно ефективного використання земель і природних ресурсів, розробку стратегічних концепцій транспортної та соціальної інфраструктури, напрацювання прототипів пілотних проєктів для залучення інвестицій, обмін досвідом та кращими практиками 3 представниками інших українських громад. За результатами діяльності програми представники органів місцевого самоврядування визначили необхідність запровадження планування інтегрованого розвитку об’єднаної територіальної громади, деякі пілотні проєкти вже реалізовано у вигляді концепцій інтегрованого розвитку міст.

Інтегрований розвиток громад зумовлює застосування нового підходу до реалізації його стратегічної політики. Цей підхід i визначається саме інтегрованим, оскільки поєднує взаємну дію економічного, соціального, екологічного i структурного розвитку територій. Концепція інтегрованого підходу у розвитку міст розроблена в 90-х pp. ХХ ст. у зв’язку 3 проєктами оновлення районів у

${ }^{4}$ Програма «Інтегроване просторове планування для об’єднаних територіальних громад» URL : https://regionet.org.ua/ua/Rozpochunaetsya_programa_Integrovane prostorove_planyvannya_dlya_obednanuh_terutorialnuh_gromad_dedlayn_280918_2634 374.html\#page_(дата звернення: 01.12.2020). 
несприятливих умовах. Інституціональна основа інтегрованого підходу до оновлення міського середовища визначена Європейською комісією шляхом пілотних проєктів, що стосуються міст 5 .

Питання інтегрованого розвитку територій та міст, що $є$ визначальними для європейської спільноти та декларовані лейпцизькою хартією «Міста Свропи на шляху до сталого розвитку», гармонізують базові чинники для напрацювання концепцій інтегрованого розвитку міст та територій. Лейпцизька хартія стійких європейських міст означує інтегрований підхід до міського планування як необхідний системостворюючий елемент довгострокового планування розвитку міст та територій. Завдяки інтегрованим проєктам місцевого планування та розвитку забезпечується поєднання пріоритетних та територіальних спрямувань громад. У нашій країні впровадження таких проєктів довгострокового планування та розвитку потребує розробки організаційних форм та удосконалення методичних та технологічних інструментів не лише в містах, а й у селах та селищах, новоутворених об'єднаних територіальних громадах, саме тому нас цікавлять у тому числі й сільські, приміські та заміські території ${ }^{6}$. Саме територіальний розвиток в умовах децентралізації та демократизації суспільних відносин спонукає до пошуку сучасних інтеграційних механізмів розвитку територіальних громад.

Сучасним інструментом ефективного місцевого розвитку визначається запровадження концепцій інтегрованого розвитку громад, що визначають довгострокові, міждисциплінарні, просторові та соціально-економічні пріоритети розвитку громад, розробляються із залученням місцевих мешканців та інших заінтересованих сторін, координуються 3 державними і регіональними програмами розвитку та $\epsilon$ передумовою розроблення містобудівної документації на місцевому рівні на принципах сталого розвитку з метою підвищення ефективності публічного управління та адміністрування, оптимізації адміністративної діяльності. Запровадження таких технологій місцевого адміністрування потребує розробки сучасних мультдисциплінарних механізмів планування інтегрованого розвитку територіальної спільноти.

Сьогодні територіальні громади міста, селища чи села означили низку проблемних напрямів, що базуються на тенденціях наслідків пострадянських управлінських рішень, зумовлені глобальними

5 Чевганова В.Я. Європейський досвід інтегрованого розвитку міст В.Я. Чевганова, О.В. Григор'єва. Економіка і регіон. 2017. № 5(66). С. 10-14.

6 Бузун О. Концепт інтегрованого розвитку самоврядних територій. URL : http://www.dridu.dp.ua/vidavnictvo/2018/2018_04(39)/25.pdf (дата звернення: 11.12.2020). 
викликами розвитку населених пунктів, особливостями історичного планування, спеціалізацією соціально-економічного розвитку. Їх вирішення на місцевому рівні потребує залучення заінтересованих сторін до процесів урядування та адміністрування розвитку, забезпечення інклюзивності простору, стійкості до змін клімату, рівного доступу до послуг та інфраструктури незалежно від наявного екологічного стану.

Чинником низького рівня розвитку підприємницької діяльності та залучення інвестицій $є$ незначна адаптація територій та просторів громад до швидких змін багатоформатного характеру у сферах виробництва та надання послуг, неефективне створення умов для забезпечення оперативного реагування місцевої бізнес-спільноти для забезпечення економічного зростання, слабкий зв'язок між питаннями просторового розвитку територій та галузевимим розвитком і залученням наявного ресурсного потенціалу. Це супроводжується застарілістю інфраструктури населених пунктів, у частині як фізичного зношення, так і низького рівня впровадження сучасних принципів, підходів та технологій, зокрема, у сферах містобудування, благоустрою, енергозбереження, інформаційного забезпечення, транспорту, поводження з відходами, розвитку людського капіталу тощо. Наслідком застарілих підходів до містобудівної діяльності та формування сфери просторового розвитку громад стали значні території, що майже не залучені до економічних процесів або сформовані як житлові зони. Це спричиняє попит на транспортні послуги всередині населених пунктів, підвищує витрати місцевих бюджетів, збільшує економічне навантаження на територіальні громади. Поряд із цим присутні тенденції регрессії традиційного середовища, зниження захисту населення від шкідливого впливу оточуючого середовища, низьке збереження та неефективне використання пам'яток архітектури та містобудування для розвитку потенціалу громад, погіршенням екологічної ситуації, незадовільним поводженням 3 об'єктами природно-заповідного фонду, пам'ятками історії та культури.

Сьогодні в Україні відсутні дієві механізми планування розвитку територій із залученням заінтересованих сторін в процесі їх розроблення. Потребує подальшої розробки та впровадження нові організаційні форми планування розвитку громад та пошук правового підгрунтя. Лише 3,3\% міст обласного значення (5 адміністративних центрів областей) та Подільський район м.Києва мають розроблені концепції інтегрованого розвитку, розроблені із залученням основних заінтересованих сторін (прогресивні девелопери, громадські організації, професійні асоціації, науково-дослідні та проєктні 
інститути, групи осіб з інвалідністю та іншими особливими потребами, різні професійні групи (медичні працівники, освітяни, екологи та інші). Лише $0,7 \%$ об'єднаних територіальних громад мають концепції інтегрованого розвитку громад, розроблені за активної участі громадськості ${ }^{7}$.

\section{2. Сучасні проскти інтегрованого розвитку територій}

Для створення конкурентоспроможних територіальних громад та подальшого їх розвитку важливими $\epsilon$ напрями формування, розробки та використання документів, в яких визначаються цілі, завдання та проєкти розвитку територій громад. Базуючись на основних положеннях Лейпцизької Хартії, залучаючи представників територіальної спільноти, місцева влада розробляє та впроваджуює Концепції інтегрованого розвитку. Вони є неформальним плануванням просторового розвитку територій, не визначені чинною нормативнозаконодавчою базою, однак у сучасних умовах трансформації суспільних відносин виступають підгрунтям для подальшої розробки генеральних планів міст та населених пунктів, детальних планів територій, іншої містобудівної документації.

$\mathrm{y}$ сучасних умовах важливим питанням постає вивчення зарубіжного досвіду планування інтегрованого розвитку міст та територій та його запровадження в нашій країні. Проєкт «Інтегрований розвиток міст в Україні» був створений у рамках міжурядової співпраці України та Німеччини. Метою проєкту є розробка та впровадження концепцій інтегрованого розвитку Подільського району м. Києва, Житомира, Полтави, Львова, Чернівців, Вінниці, Мелітополя, Харкова 3 урахуванням потреб всіх верств населення та територіальної громади. Виконавцем проєкту стала німецька урядова компанія «Deutsche Gesellschaft für Internationale Zusammenarbeit (GIZ) $\mathrm{GmbH}$ », а фінансують його Уряди Німеччини та Швейцарії. Уряд Німеччини фінансує проєкт у розмірі 7,25 млн євро, Уряд Швейцарії надає 1,85 млн євро.

Метою Концепції інтегрованого розвитку Подільського району м. Києва $є$ окреслення ключових просторових та змістовних принципів розвитку району на найближчі 10 років. У розробці брали участь

7 “Про схвалення Концепції запровадження інтегрованого розвитку громад та затвердження плану заходів 3 iї реалізації Проект розпорядження Кабінету Міністрів України. URL : https:/www.minregion.gov.ua/base-law/gromconvers/elektronni-konsultatsiyi-z-gromadskistyu/proekt-rozporyadzhennya-kabinetuministriv-ukrayini-pro-shvalennya-kontseptsiyi-zaprovadzhennya-integrovanogorozvitku-gromad-ta-zatverdzhennya-planu-zahodiv-z-yiyi-realizatsiyi/ (дата звернення: 01.12.2020). 
представники державної, міської та районної влади, члени партнерських організацій, кияни й мешканці Подільського району. Проєкт «Інтегрований розвиток міст в Україні» впроваджений в шести містах, а у 2018 році до проєкту долучився Подільський район Києва. Він співмірний таким містам, як Житомир або Чернівці, кількість населення майже 300000 мешканців та складається із трьох частин: Старий Поділ, Куренівка та Виноградар. Інтегроване міське планування району великого міста $\epsilon$ інструментом до створення стратегій просторового розвитку, що передбачає залучення усіх зацікавлених сторін та тісну міждисциплінарну взаємодію ${ }^{8}$.

Концепція інтегрованого розвитку Подільського району м. Києва передбачає реалізацію кількох великих проєктів: реконструкцію Контрактової площі, пішохідної частини вулиці Сагайдачного, оновлення деяких кварталів на старому Подолі, реновацію колишніх промислових територій старих заводів. У баченні розробників концепції, якість життя жителів Подолу покращать формування зелених вулиць; облаштування зелених публічних просторів; розвиток інфраструктури для перебування людей: велодоріжки, альтанки, спортивні майданчики, променадні стежки; охорона i підтримка кладовищ; збереження цінних ландшафтів шляхом накладення мораторію на будівництво; підтримка територій садибної забудови; озеленення промислових зон; облаштування парку на Рибальському острові із публічним простором, пішохідною та велосипедною інфраструктурою; бульвари зазнають комплексної трансформації; відновлення місцевих малих річок і струмків.

Інтегрована концепція розвитку центральної частини Львова задіяла приблизно 90 українських та міжнародних експертів із містопланування, транспорту, архітектури й соціології. Інтегрована концепція $\epsilon$ практичним посібником, в якому зібрано усі важливі проєкти з розвитку історичної частини Львова, що заплановані на наступні 10 років. Розрізняють проєкти, які перебувають на стадії впровадження, та ідеї проєктів, що повинні впроваджуватися міською радою чи іншими громадськими організаціями, заходи об'єднано відповідно до тематичних груп: культурна спадщина міста, житлове господарство, громадський простір, транспортна та технічна інфраструктура, економіка та торгівля, туризм, соціальна та культурна сфери. Також всі проєкти нанесено на тематичну та загальну карту, де видно тісні зв'язки між окремими секторами та взаємодію між ними.

\footnotetext{
8 У вересні буде презентовано напрацьований із громадою проект Концепції інтегрованого розвитку Подільського району. URL https://podil.kyivcity.gov.ua/news/13702.html (дата звернення: 19.12.2020).
} 
Використання потенційного ефекту взаємодії проєктів $є$ важливою складовою стратегічного підходу до майбутнього розвитку міста ${ }^{9}$.

Інтегрована концепція розвитку центральної частини Львова конкретизує загальні цілі розвитку історичної частини міста, зокрема, «Стратегію сталого розвитку міста Львова» та «Стратегічний план збереження історичного центру у Львові», на основі генерального плану. В Інтегрованій концепціії розвитку центральної частини Львова аспекти енергозбереження та сталого розвитку присутні у всіх сферах. Між окремими галузями $є$ тісний зв'язок та взаємні впливи. Підтримка i використання можливих синергетичних ефектів $є$ важливою складовою стратегічних засад майбутнього розвитку міста. Зона дії Інтегрованої концепції розвитку центральної частини Львова охоплює площу близько 1,9 км², територія орієнтується головним чином на межі, визначені ареалом культурної спадщини ЮНЕСКО, частина охопленого проєктом ареалу розташована на території Галицького району міста, а також у Личаківському районі міста.

Цікавим аспектом Інтегрованої концепції розвитку центральної частини Львова $\epsilon$ поєднання публічних інвестицій та приватних вкладень, що найбільш актуально для старих житлових будинків поблизу міських парків та скверів. Концентрація фінансових надходжень на території незначного простору може надати найбільший позитивний ефект для міського розвитку.

В Інтегрованій концепції розвитку Полтави 2030 визначено шість пріоритетних сфер розвитку міста, визначаються шляхи досягнення диверсифікації економіки креативними та екологічно дружніми індустріями, посилення позицій Полтави як міста обласного значення, розвитку сфери туризму та рекреації, вирішення питань розвитку житлової сфери та створення Плану сталої мобільності міста.

Суть концепції у тому, що життя у місті треба планувати так, щоби людям було зручно на вулицях, з'явилося більше туристів, а інвестори захотіли вкладати кошти в різні проєкти. У концепції «Полтава 2030» міститься 62 проєкти, які мають зробити місто кращим. Виділимо із них ті, які стосуються конкретних дій:

1) Реконструкція вулиці Соборності. Продовжити пішохідну зону вулиці Соборності від «Злато місто» до вулиці Конституції, включаючи Петровський парк. Площу перед театром ім. Гоголя облаштувати сухими фонтанами та артоб'єктами.

2) Реконструкція Центрального ринку.

9 Інтегрована концепція дій для центральної частини міста. URL http://www.urban-project.lviv.ua/ua/gtz-projects/instrumenty-planuvannya/konceptsiyadiy (дата звернення: 12.12.2020). 
3) Планування Київської промзони.

4) Будівництво конгрес-центру, бізнес-парку, тренінгового центру.

5) Інвентаризація зовнішньої реклами під один стандарт.

6) Будівництво нового житла.

7) Ревіталізація промислових зон. Реновація колишніх промислових приміщень в арт-обєкти: виставки, спортивні майданчики.

8) Створення Програма енергоефективності.

9) Екобудівництво.

10)Вуличне освітлення на сонячних батареях.

11)Дендропарк-Поле Полтавської битви.

12)Будівництво сімейного парку розваг «Полтава Ленд».

13)Будівництво реабілітаційного центру для оздоровлення людей.

14)Будівництво лабораторії, яка буде слідкувати за станом довкілля у місті.

15)Будівництво сонячної електростанції потужністю 20 МВт на рік.

16)Створення PR-відділу в міськвиконкомі, який займатиметься піаром і рекламою міста.

Виходячи 3 поставлених завдань розвитку у 2030 році Полтава має бути: містом з диверсифікованим екологічно чистим виробництвом; містом прикладних наук, освіти, економіки знань та креативних індустрій; потужним регіональним центром та осередком української культури; привабливим туристичним центром, центром рекреації та реабілітації; містом комфортного проживання мешканців ${ }^{10}$.

Концепція інтегрованого розвитку Житомира 2030 визначає основні напрямки розвитку міста, дозволяє збільшити рівень добробуту і задоволеності громади, залучити міжнародних інвесторів та донорів, адже однією 3 основних умов сталого розвитку громади в умовах децентралізації $\epsilon$ наявність стратегії розвитку. Житомир працює у цьому напрямку разом із Полтавою, Вінницею, Чернівцями, Львовом, Харковом, Мелітополем і Подільським районом Києва. Проєкт має назву «Інтегрований розвиток міст в Україні ІІ» та фінансується Урядами Німеччини та Швейцарії. Концепція інтегрованого розвитку визначає Житомир як ефективне, інноваційне, активне, комфортне, зелене, інклюзивне місто.

Ідея розробки Концепції інтегрованого розвитку та різноманітних інвестиційних проєктів передбачає обмін досвідом з іншими містами. Окрім Концепції інтегрованого розвитку Житомира до 2030 року, в рамках Проєкту було розроблено План сталої міської мобільності із залученням широкого кола експертів та місцевих жителів. План

10 Полтава - 2030: інтегрований розвиток міста. URL : http://www.2030.poltava.ua/ua/ (дата звернення: 12.12.2020). 
сталої міської мобільності визначає шість пріоритетів розвитку мобільності м. Житомир, а також заходи для кожного пріоритету, які базуються на аналізі існуючої ситуації та поставлених цілей розвитку мобільності. Працівники органів місцевого самоврядування взяли участь в тренінгах та семінарах за програмою підвищення кваліфікації «Кваліфікація 2030». Навчальні заходи дозволили покращити співпрацю, комунікацію та координацію між різними структурними підрозділами Житомирської міської ради. Учасники розширили свої знання у сферах поводження з відходами на муніципальному рівні, міської мобільності та проєктного менеджменту. Варто зауважити, що проєкт дозволив активізувати громадянське суспільство в місті та започаткував нові практики залучення громадян до процесів планування та розвитку міста шляхом проведення форумів інтегрованого розвитку, щорічного урбаністично-культурного фестивалю «Майстерня міста Житомир», фокус-груп, різноманітних урбан-зустрічей та інших громадських заходів. На цій платформі аналізується інформаційна складова інтегрованого розвитку Житомира ${ }^{11}$.

Завдяки розробленню «Інтегрованої концепції розвитку середмістя Чернівців» місто одним із перших в Україні отримало сучасний європейський інструмент містопланування ${ }^{12}$, сформульовано стратегію сталого розвитку кварталів середмістя, визначено основні зони діяльності за такими напрямами, як «Містобудування та житло», «Транспорт», «Технічна інфраструктура», «Культура та культурна спадщина», «Освіта, наука та соціальна політика», «Економіка та зайнятість», «Туризм», «Громадський простір», «Екологія і захист клімату» та «Модернізація управління». Реалізація перерахованих у цих розділах проєктів запланована на наступні 15 років.

Сфера дії інтегрованої концепції для середмістя Чернівців простягається на площі 650,65 га. Проєктна територія включає історичне середмістя, територію колишньої резиденції митрополитів Буковини та Далмації, що є об'єктом всесвітньої спадщини UNESCO, а також територію між вокзалом та рікою Прут. Відповідно до цієї стратегії до 2030 року Чернівці мають стати містом традицій та майбутнього; містом з гідними умовами проживання для всіх груп мешканців; зростаючим культурним, туристичним та економічним центром; компактним містом з ефективними системами комунальних

11 Інтегрований розвиток Житомира. URL : https://2030.zhitomir.ua (дата звернення: 12.12.2020).

12 Інтегрована концепція розвитку середмістя Чернівців : проект «Муніципальний розвиток та оновлення старої частини міста Чернівці» Німецького товариства міжнародного співробітництва (GIZ) ГмбX / Чернівецька міська рада. 2015. 54 с. 
послуг, зеленим та екологічним містом; містом із сучасною міською адміністрацією.

Інтегрована концепція розвитку середмістя визначає Чернівці як місто із сучасною та якісною інфраструктурою, місто науки та креативної економіки, інноваційне місто культури й традицій, місто туризму й торгівлі, комфортне для проживання місто, місто здорових людей ${ }^{13}$. Окрім цього, визначено секторальні концепції реалізації проєкту щодо розвитку торгівлі, співпраці з регіоном, розвитку житлових районів. Відповідно до поставлених цілей на конкурсній основі вибрано низку проєктів та заходів, які будуть реалізовані до 2030 року.

Концепція інтегрованого розвитку міста Вінниця 2030 також $\epsilon$ основою розвитку відповідної території. Цей документ визначає просторові та змістові пріоритети і є другим за значенням документом цілісного розвитку міста після Генерального плану та слугує основною передумовою для більш детального планування галузей розвитку міста, описує планування від абстрактного до конкретного - має частину із загальним описом візій розвитку міста, проєкти та визначені заходи в кожній із сфер життя та діяльності, базується на міжнародних принципах сталого розвитку. Такий підхід дає місту можливість слідкувати за тенденціями розвитку міст України та інших країн, зокрема європейських, і в порівнянні розуміти свої слабкі та сильні сторони. Концепція інтегрованого розвитку міста Вінниця 2030 $\epsilon$ наступницею Стратегії розвитку Вінниці 2020 та іiі логічним продовженням $^{14}$.

Це означає, що місто розпочало більш комплексно, цілісно, інтегровано розглядати свій розвиток і усвідомлювати необхідність залучення широкого кола учасників до планування та реалізації цілей.

Паралельно 3 напрацюванням Вінниці у рамках проєкту «Інтегрований розвиток міст в Україні» було дано старт іншим важливим інфраструктурним проєктам, які мають реалізовуватися за принципами інтегрованості та справляють міжсекторальний вплив на розвиток окремих районів міста. Два такі проєкти стосуються району Замостя. Це інфраструктурний проєкт “Вінницька Миля”, який передбачає комплексну реконструкцію проспекту Коцюбинського, створення комфортного міського середовища для жителів і користувачів цієї вулиці. Ще один проєкт - реконструкція парку

13 Інтегрована концепція розвитку Чернівців - 2030 (ІКРМ - 2030) (проект). Чернівці, 2018. 173 с.

14 Концепція інтегрованого розвитку міста Вінниці 2030. URL : https://www.vmr.gov.ua/Lists/IntegratedUrbanDevelopment/Default.aspх(дата звернення: 12.12.2020). 
«Хімік». Хоча він $€$ інфраструктурним, його основна мета напрацювання кейсу з партисипації жителів міста на початкових етапах створення проєктів міського розвитку. Інший проєкт стосується створення транспортної моделі міста, яка, враховуючи головні ідеї цієї Концепції, має на меті створення оптимальної моделі розвитку міської мобільності Вінниці. Хоча ці проєктні ідеї розробляли паралельно, вони органічно включені як проєкти у візіях і галузевих частинах Концепції інтегрованого розвитку міста Вінниця 2030, оскільки $\epsilon$ міжгалузевими, а їх реалізація матиме значний вплив на окремі сфери життя та окремі райони міста.

Загалом. до кінця 2023 року Вінниця, Житомир, Полтава, Чернівці, Львів та Подільський район Києва будуть впроваджувати Концепції інтегрованого розвитку міст та План сталої міської мобільності, а нові учасники, міста Харків та Мелітополь розроблятимуть ці стратегічні документи. До цього процесу залучатимуться громадські організації та мешканці міст. Разом із представниками громади міста будуть продовжувати роботу над пріоритетними проєктними документаціями.

До другої фази проєкту «Інтегрований розвиток міст в Україні» було відібрано місто Мелітополь. Для розвитку міста проєкт визначає розробку планів інтегрованого розвитку міста, стійкої мобільності, розробку документації для інфраструктурних проєктів. Важливість співпраці місцевої влади та територіальної спільноти в рамках зазначеного проєкту дозволить мешканцям міста більш повно розуміти процеси інтегрованого розвитку ${ }^{15}$.

Харків також приєднався до другої фази європейського проєкту «Інтегрований розвиток міст в Україні». Представники міської влади та представники Державного секретаріату 3 економічних питань Швейцарської Конфедерації (SECO), Швейцарського бюро співробітництва в Україні, Німецької федеральної компанії «GIZ», Львівської, Полтавської, Мелітопольської, Вінницької, Житомирської, Чорновицької міських рад та міста Києва, які беруть участь у проєкті підписали протокол про співпрацю з Німецькою федеральною компанією «GIZ» в рамках реалізації проєкту «Інтегрований розвиток міст в Україні II». Проєкт передбачає консультаційну підтримку експертів, обмін досвідом, підвищення кваліфікації співробітників міської ради, розробку концепції інтегрованого розвитку, плану стійкої мобільності і реалізацію демонстраційного проєкту. Таким може стати, зокрема, включення в план району елементів для маломобільних груп населення.

15 Мелітопольська міська рада. Офіційний інтернет-портал. URL : http://mlt.gov.ua/index.php (дата звернення: 12.12.2020). 
Харків - передове місто з сильною освітянською складовою, друге за чисельністю населення в країні. Місто приєднується до всеукраїнської мережі міст, які співпрацюють у вирішенні різних питань 3 розвитку, а також мають доступ до профільного міністерства для налагодження співпраці. Такий підхід 3 розробки концепції інтегрованого розвитку є новим в Україні, тому вимагає підтримки міжнародних експертів ${ }^{16}$.

Досвід розроблення та реалізації Концепцій інтегрованого розвитку міст може бути використаний іншими містами України. Міста в Україні мають концентроване уявлення про загрози й виклики, що існують у зовнішньому середовищі, а також суттєво впливають на добробут і можливості сталого розвитку. Першочерговим напрямом планування інтегрованого розвитку міст $\epsilon$ вибір проєктів та заходів, здатних досягти стратегічних та операційних цілей найбільш ефективним способом. При цьому найбільш вагомими стають не лише кількість та масштаби фінансування проєктів, але й механізми їх реалізації на сучасному етапі.

Найбільш за все територіальні громади потребують сьогодні зміцнення економічної складової розвитку та ефективної політики щодо зайнятості населення. При цьому комфортність територій для мешканців має не менше значення, ніж рівень доходів, і ці напрями забезпечуються можливостями впровадження ефективних управлінських практик. Застосування досвіду планування інтегрованого розвитку територіальних громад має грунтуватись на науковому дослідженні реального стану всіх сфер життєдіяльності спільноти, визначенні проблем та шляхів їх вирішення, окресленні пріоритетів та поєднанні всіх складових місцевого розвитку.

\section{ВИСНОВКИ}

У процесі систематизації основних дослідницьких підходів до розкриття сутності проєктного підходу у сфері планування інтегрованого розвитку територіальних громад установлено, що інтегрований розвиток на місцевому рівні зумовлює застосування нових підходів до реалізації пріоритетів розвитку спільнот, що поєднує взаємну дію економічного, соціального, екологічного і структурного розвитку територій.

16 Харків приєднався до нового проєкту розвитку міст 3 урахуванням європейських стандартів. URL : https://www.city.kharkov.ua/uk/news/kharkivpriednavsya-do-novogo-proektu-rozvitku-mist-z-urakhuvannyam-evropeyskikhstandartiv-43236.html (дата звернення: 19.12.2020). 
При цьому планування інтегрованого розвитку громад варто розуміти як одночасне врахування максимального числа потреб та інтересів, що будуть відповідати або відповідають потребам громади та поєднують діяльність просторових, секторальних і пріоритетних напрямів розвитку територіальної спільноти. При цьому інтегрований підхід передбачає також узгодження потреб бізнесу у розвитку території і тих переваг, які може надати той чи інший планувальний проєкт населенню.

Територіальні спільноти мають стати більш самостійним у питаннях публічного управління та адміністрування, в можливості розроблення й підтримки особливих, інколи притаманних тільки одній або декільком територіальним громадам показників якості життя та діяльності.

Процес планування інтегрованого розвитку територіальних громад визначає комплексний підхід до визначення майбутнього розвитку територій з урахування пріоритетів саме цієї спільноти та впорядковує усі містобудівні процеси. Концепція інтегрованого розвитку територій як інструмент підвищення ефективності місцевого врядування повинна бути побудована на чітких принципах, конкретних цілях та визначати спільні просторові наміри громади. Виникнення цілої низки концепцій інтегрованого розвитку місцевих громад визначене особливостями трансформаційного періоду розвитку міст та необхідністю вирішення конкретних проблем.

У сучасних умовах застосування проєктного підходу до впровадження інтегрованого розвитку територіальних громад надає можливість використання кращих зарубіжних та вітчизняних практик на основі нового інноваційного комплексного підходу і міжвідомчої співпраці за різними напрямами.

\section{АНОТАЦІЯ}

Стаття присвячена вивченню проєктного підходу у сфері планування інтегрованого розвитку територіальної громади. Досліджено сучасні умови управління інтегрованим розвитком територіальних спільнот, розкрито особливості здійснення його планування в сучасних умовах трансформаційних перетворень. Визначено, що сучасний розвиток інтегрованого планування територіальної громади як складової частини публічного управління та адміністрування недостатньо досліджений. Здійснено аналіз сучасного стану форм та методів забезпечення інтегрованого розвитку громад в Україні.

Охарактеризовано пріоритетні напрями у сфері планування інтегрованого розвитку територіальних громад в країні на засадах сталого розвитку. Визначенно, що ефективних інструментом планування інтегрованого розвитку територіальної громади в сучасних умовах 
є запровадження проєктного підходу. У цьому аспекті Концепція інтегрованого розвитку територій як інструмент підвищення ефективності місцевого врядування повинна бути побудована на чітких принципах, конкретних цілях та визначати спільні просторові наміри громади.

\section{ЛІТЕРАТУРА}

1. «Перетворення нашого світу: Порядок денний в області сталого розвитку на період до 2030 року» Резолюція Генеральної Асамблеї OOH. URL : http://sdg.org.ua/ua/resources-2/344-2030-2015(дата звернення: 19.11.2020).

2. «Про Цілі сталого розвитку України на період до 2030 року» Указ Президента України від 30.09.2019 № 722/2019. URL : https://www.president.gov.ua/documents/7222019-29825 (дата звернення: 01.12.2020).

3. Лейпцизька Хартія «Міста Свропи на шляху сталого розвитку». URL : http:/ /2.auc.org.ua/sites/default/files/leypcizka_hartiya.pdf (дата звернення: 10.11.2020).

4. Програма «Інтегроване просторове планування для об'єднаних територіальних громад» URL https://regionet.org.ua/ua/Rozpochunaetsya_programa_Integrovane_prostoro ve_planyvannya_dlya_obednanuh_terutorialnuh_gromad_dedlayn_280918_ 2634374.html\#page_(дата звернення: 01.12.2020).

5. Чевганова В.Я. Європейський досвід інтегрованого розвитку міст / В.Я. Чевганова, О.В. Григор'єва. Економіка $i$ регіон. 2017. № 5(66). C. 10-14.

6. Бузун О. Концепт інтегрованого розвитку самоврядних територій. URL : http://www.dridu.dp.ua/vidavnictvo/2018/2018_04(39)/25.pdf (дата звернення: 11.12.2020).

7. «Про схвалення Концепції запровадження інтегрованого розвитку громад та затвердження плану заходів 3 iї реалізації» : Проект розпорядження Кабінету Міністрів України. URL : https://www.minregion.gov.ua/base-law/grom-convers/elektronnikonsultatsiyi-z-gromadskistyu/proekt-rozporyadzhennya-kabinetu-ministrivukrayini-pro-shvalennya-kontseptsiyi-zaprovadzhennya-integrovanogorozvitku-gromad-ta-zatverdzhennya-planu-zahodiv-z-yiyi-realizatsiyi/ (дата звернення: 01.12.2020).

8. У вересні буде презентовано напрацьований із громадою проект Концепції інтегрованого розвитку Подільського району. URL : https://podil.kyivcity.gov.ua/news/13702.html (дата звернення: 11.12.2020). 
9. Інтегрована концепція дій для центральної частини міста. URL : http://www.urban-project.lviv.ua/ua/gtz-projects/instrumentyplanuvannya/konceptsiya-diy (дата звернення: 12.12.2020).

10. Полтава - 2030: інтегрований розвиток міста. URL : http://www.2030.poltava.ua/ua/ (дата звернення: 12.12.2020).

11. Інтегрований розвиток Житомира. URL : https://2030.zhitomir.ua (дата звернення: 12.12.2020).

12. Інтегрована концепція розвитку середмістя Чернівців : проект «Муніципальний розвиток та оновлення старої частини міста Чернівці» Німецького товариства міжнародного співробітництва (GIZ) ГмбX / Чернівецька міська рада. 2015. 54 с.

13. Інтегрована концепція розвитку Чернівців - 2030 (проект). Чернівці, 2018. 173 с.

14. Концепція інтегрованого розвитку міста Вінниці 2030. URL : https://www.vmr.gov.ua/Lists/IntegratedUrbanDevelopment/Default.aspx(да та звернення: 12.12 .2020$)$.

15. Мелітопольська міська рада. Офіційний інтернет-портал. URL : http://mlt.gov.ua/index.php (дата звернення: 12.12.2020).

16. Харків приєднався до нового проєкту розвитку міст 3 урахуванням європейських стандартів. URL : https://www.city.kharkov.ua/uk/news/kharkiv-priednavsya-do-novogoproektu-rozvitku-mist-z-urakhuvannyam-evropeyskikh-standartiv43236.html (дата звернення: 19.12.2020).

17. Ресурсне забезпечення об'єднаної територіальної громади та іiі маркетинг : практ. посіб. / Г.А. Борщ, В.М. Вакуленко, Н.М. Гринчук, Ю.Ф. Дехтяренко, О.С. Ігнатенко, В.С. Куйбіда, А.Ф. Ткачук, В.В. Юзефович. Київ, 2017. 107 с .

18. Місцеве самоврядування : підручник / за ред. В.М. Вакуленка, Ю.Ф. Дехтяренка, В.С. Куйбіди. Київ : НАДУ, 2019. 672 с.

\section{Information about the author:} Viakhiriev M. O.,

Postgraduate Student at the Department of Regional Management, Local Self-Government and City Management National Academy for Public Administration under the President of Ukraine 20, Anton Tsedik str., Kyiv, 03057, Ukraine 